\title{
Amylolepiota, Clavicybe and Cystodermella, new genera of the Agaricales
}

\author{
HARRI HARMAJA
}

\begin{abstract}
HARMAJA, H. 2002: Amylolepiota, Clavicybe and Cystodermella, new genera of the Agaricales. - Karstenia 42: 39-48. Helsinki. ISSN 0453-3402.

Lepiota lignicola P.Karst., is referred to Amylolepiota Harmaja, n. gen., as Amylolepiota lignicola (P.Karst.) Harmaja, n. comb. Clitocybe clavipes (Pers. : Fr.) P.Kumm. (as the type) and two related species are separated from the externally very similar Clitocybe (Fr.) Staude to form a new genus, Clavicybe Harmaja. Clavicybe differs from Clitocybe: (i) the spore surface appears rough with a high magnification, the anatomy deviates as (ii) the hygrophanity of the fruit body is different and (iii) the gill trama is irregular. A key to the species is given. 3 new nomenclatural combinations in Clavicybe are made: C. avellaneialba (Murrill) Harmaja, C. clavipes (Pers. : Fr.) Harmaja, and C. squamulosoides (P.D.Orton) Harmaja. A third new genus, Cystodermella Harmaja, is described for a group of species with inamyloid spores segregated from Cystoderma Fayod. 12 new nomenclatural combinations in Cystodermella are made: $C$. adnatifolia (Peck) Harmaja, C. ambrosii (Bres.) Harmaja, C. cinnabarina (Alb. \& Schwein. : Fr) Harmaja, C. contusifolia (Pegler) Harmaja, C. cristallifera (Thoen) Harmaja, C. elegans (Beeli) Harmaja, C. granulosa (Batsch : Fr.) Harmaja (type species of Cystodermella), C. japonica (Thoen \& Hongo) Harmaja, C. luteohemisphaerica (Dennis) Harmaja, C. myriadocystis (Heinem. \& Thoen) Harmaja, C. sipariana (Dennis) Harmaja, and C. subpurpurea (A.H.Sm. \& Singer) Harmaja. Special attention was paid to correct nomenclature and author citations.
\end{abstract}

Key words: amyloidity, arthrospores, Clitocybe, Cystoderma, Finland, Floccularia, gill trama, hygrophanity, Lepiota, nuclear DNA content, Ripartitella, Squamanita

Harri Harmaja, Botanical Museum, Finnish Museum of Natural History, P.O. Box 47, FIN-00014 University of Helsinki, Finland www.helsinki.fi/people/harri.harmaja/

\section{AMYLOLEPIOTA}

I am lucky enough to be among the very few people who have seen the unusual agaric Lepiota lignicola P.Karst. in the nature. This species was described in 1879 from southern Finland. According to my judgement, L. lignicola must be classified in a separate, new genus as described below.

\section{Amylolepiota Harmaja, n. gen.}

?Lepiota sect. Amyloideae Singer, Ann. Mycol. 41: 171. 1943. - Holotype: Lepiota amyloidea Singer. This synonymy is true if $L$. amyloidea is synonymous with $L$. lignicola as claimed by Knudsen (1980).

Agaricalium generis Lepiotae affinis. Ab ea differt sporis amyloideis habitationeque ligno. Epicutis e cellulis elongatis instructa. Rarissime occurrit in silvis borealibus vetustis. - Typus: Amylolepiota lignicola (P.Karst.) Harmaja (Lepiota lignicola P.Karst.).

Basidiocarp medium-sized. Universal veil apparently present; presence of partial veil unclear. Pi- 
leus convex to plane; surface dry, with appressed to squarrose brown scales. Stipe without ring; surface dry, below the ring zone with squarrose scales like those of pileus. Lamellae free, whitish. Flesh white, not changing. Odour not distinctive. Taste mild. Spores pure white in fresh deposit (pale yellow in age), binucleate, ellipsoid; wall without germ-pore, hyaline, smooth, distinctly amyloid, cyanophilic, but carminophobic. Basidia with basal clamp, without carminophilic/siderophilic granulation; wall carminophobic, with a thin cyanophilic inner layer towards apex. Cheilocystidia present, inconspicuous; pleurocystidia lacking. Epicutis, also in scales, of cells which are distinctly longer than wide; pigment essentially membranal. Hymenophoral trama regular. Clamp connections present in hyphae of fruit body. Dried pileus, stipe, lamellae, basal mycelium, flesh and spore deposit do not exhibit fluorescence but retain their colours under ultraviolet light (with wave-lengths $254 \mathrm{~nm}$ and 366 $\mathrm{nm}$ ), excepting the tinges of the three first-named structures which become slightly deeper. Habitat on decaying wood (always of Betula ?) in forest; causes white rot.

The above description is based on my studies of fresh and dried fruit bodies of the type species. Included are the first reports of the responses of its basidiocarp to ultraviolet light and of its spores and basidia to the reagents methyl (cotton) blue and acetocarmine.

Amylolepiota is closely related to the agaric genus Lepiota Gray (type species L. clypeolaria (Bull. : Fr.) P.Kumm.); the fruit bodies remind those of the species of sect. Echinatae Fayod of the latter genus. The lamellae are likewise free in the new genus, but their proximal ends reach closer to the stipe apex than in Lepiota. The decisive differences are the amyloid spore wall and the lignicolous habit of Amylolepiota. In Lepiota the spore wall is dextrinoid and the species are saprophytes on bare humous soil or in nonwoody litter. However, L. zenkeri Henn. has an amyloid spore wall; it has been included in a section of its own (Singer 1986). L. zenkeri does not appear to belong to Amylolepiota: it occurs in tropical Africa on non-ligneous substrate. Cystolepiota Singer differs from Amylolepiota by possessing uninucleate inamyloid spores, a pileus cortex of sphaerocysts, and non-woody habitat. Leucopholiota (Romagn.) O.K.Mill., T.J.Volk \& Bessette (Miller \& al. 1996) differs by having rather broadly adnate lamellae: see the original illustration of the type species, Agaricus decorosus Peck (Peck 1873) [Romagnesi (1989) suggested that $L$. lignicola and $A$. decorosus would be identical]. In Cystoderma Fayod s. str., as restricted by me in this paper (see below), the universal veil is essentially composed of sphaerocysts and the lamellae are not free but adnate.

Most probably the new genus contains a single species only; the necessary new combination is made below. However, Cystoderma carpaticum M.M.Moser, an enigmatic fungus based on a single specimen from Poland (Moser 1979), should be compared when more material is available.

Amylolepiota lignicola (P. Karst.) Harmaja, n. comb.

Coloured illustrations: Karsten 1883: fig. 1; Korhonen 1991: Sienilehti 43(1), back cover

Basionym: Lepiota lignicola P.Karst., Bidrag Kännedom Finlands Natur Folk 32 [Ryssl. Hattsvamp. 1]: 547. 1879. - Cystolepiota lignicola (P.Karst.) Nezdojm., Mikol. Fitopatol. 14: 389. 1980. - Holotype: Finland, Etelä-Häme, Tammela, Mustiala, in ligno mucido betulae, IX.1879 P.A. Karsten (H: Herb. P.A. Karsten no. 2034). - Other specimens examined (also when fresh): Finland, Etelä-Häme, Lammi, Evo, virgin forest 'Kotisten aarnialue', 11.IX.1973 H. Harmaja (H); exactly the same place, 11.IX.1973 U. Kurimo $(\mathrm{H})$.

?Lepiota amyloidea Singer, Ann. Mycol. 41: 171. 1943. - Holotype: Russia, Altay Republic (as 'Oirotia, Altai'), Lake Teletskoe (LE, n.v.). Knudsen (1980) synonymizes this species with L. lignicola.

A detailed description of the species is given by Knudsen (1980, as Lepiota).

In Finland A. lignicola possesses a specific habitat ecology: the species is restricted to mesic old-growth forest in the southern boreal zone; the substrate is decaying wood, a fallen log or larger branch of Betula lying on the ground (it is unknown whether $B$. pendula, $B$. pubescens or both are concerned). The species is classified as critically endangered (CR) in Finland according to the latest Red List of Finland (Rassi \& al. 2001).

During the mycology courses of the University of Helsinki, arranged at Lammi (S. Finland), the fungus was found in the same locality at Kotinen 
Virgin Forest in five successive years (1972-1976), probably on the same decaying Betula log!

In total, specimens examined by me or literature reports that appear reliable show that $A$. lignicola has been found ( $i$ ) in three localities in the inland of South Finland (in the province of EteläHäme, latest in 1985; according to specimens in $\mathrm{H})$, (ii) in the Republic of Karelia, Russia (Kotiranta \& al. 1998), and (iii) in several localities throughout the Asian part of Russia (Singer 1943 if the synonymy indicated by Knudsen [1980] is approved), Vasil'eva 1973, Nezdojminogo 1982, Petrov 1986, Kutafyeva 1989 [recorded as L. hystrix Möll. \& J.Lange but most probably referring to the present species], Astapenko \& Kutafyeva 1990, Lapitskaya 1993, Gorbunova 2001). To my judgement, the records from the U.S.A. (Knudsen 1980) and Mexico (Cifuentes \& al. 1989, as $L$. amyloidea) require further study, as does the lignicolous 'Lepiota hispida Lasch' from Italy (Bresadola 1927).

\section{CLAVICYBE}

A monograph on the genus Clitocybe (Fr.) Staude in Fennoscandia (northwestern Europe) constituted my Ph.D. thesis (Harmaja 1969). In that contribution, I reported 43 species from the study area; they were placed in 3 subgenera and 16 sections, and I considered the genus clearly heterogeneous. C. clavipes (Pers. : Fr) P.Kumm. was assigned to a section of its own. Later I separated a part of the species and transferred them to Lepista (Fr.) W.G.Sm. or Singerocybe Harmaja (Harmaja 1974a, 1974b, 1976, 1988). Even after these procedures, Clitocybe still did not appear natural.

Among the Fennoscandian species, Clitocybe clavipes was found by me (Harmaja 1969) unique in four respects: (i) the pileus is not hygrophanous though the flesh has this character, (ii) the wet cap flesh begins to dry and fade from the periphery towards the centre, (iii) the trama of the lamellae is constructed of interwoven hyphae (vs. parallel or subparallel), and (iv) the spores contain a distinct, large, refractive oil drop. As in addition Pegler \& Young (1971) found that, with a high magnification under the electron microscope (they used the carbon replica method), the spores of this species have a roughened surface, I planned to create for C. clavipes a genus of its own in the 1970's. Moreover, C. clavipes has been found "poisonous": the antabuse-like reaction (i.e., that of the disulfiramtype) results when fruit bodies heated for food are consumpted with alcohol (e.g. Cochran \& Cochran 1978, Bresinsky \& Besl 1985).

In a very recent phylogenetic analysis of a great number of agarics and related species (Moncalvo \& al. 2002), the position of C. clavipes was somewhat peculiar which might support the establishment of a separate genus for the species.

Two additional species are included in Clavicybe: Clitocybe avellaneialba Murrill and Clitocybe squamulosoides P.D.Orton. The affinity of the former species to Clitocybe clavipes was earlier stated by me (Harmaja 1969); the latter was previously thought by me to represent a form of C. clavipes (Harmaja 1970).

\section{Clavicybe Harmaja, n. gen.}

Clitocybe subg. Clitocybe sect. Clavipedes Harmaja, Karstenia 9: 58. 1969. - Type: Clitocybe clavipes (Pers. : Fr.) P.Kumm.

Clitocybe subg. Infundibuliformes sect. Inornatae subsect. Albiphyllae H.E.Bigelow, Beih. Nova Hedwigia 72: 193. 1982. - Type: Clitocybe avellaneialba Murrill.

Clitocybe subg. Hygroclitocybe Bon, Doc. Mycol. 13(51): 9. 1983. - Type: Clitocybe clavipes (Pers. : Fr.) P.Kumm.

Agaricalium genus. Genus Clitocybem in mentem revocat. Ab ea inter alia differt sporis subtilissime rugulosis tramaque lamellarum $e$ hyphis intricatis instructa. - Typus: Clavicybe clavipes (Pers. : Fr.) Harmaja (Agaricus clavipes Pers. : Fr.).

Agaricales; habitus of basidiocarp as in Clitocybe. Veil completely absent. Pileus from convex to plane or somewhat depressed, not hygrophanous, brown or grey-brown; surface dry. Stipe usually clavate, concolorous with pileus; surface dry. Lamellae decurrent, whitish. Odour sweetish or indistinct. Taste mild. Flesh hygrophanous; cap flesh dries from the periphery towards the centre. Spores pure white in fresh deposit (pale yellow in age), not sticking to tetrads or with collapsed walls in mounts made of dry gills, fairly large, a proportion of them always broadly fusiform; uninucleate (Kühner 1945); wall without germ-pore, hyaline, inamyloid, cyanophobic (Singer 1972, Harmaja 1974a, 1976, 1979b), rugu- 
lose under the electron microscope at least in the type species (Pegler \& Young 1971, Bigelow 1981); contents with one distinct oil drop; hilar appendix large, ca. 0.9-1.1 $\times 0.7-0.9 \mu \mathrm{m}$. Cystidia of any kind absent. Pileus cortex made of epicutis and subcutis of subparallel hyphae; pigment essentially situated within cells of epicutis. Hymenophoral trama irregular, i. e., composed of interwoven hyphae (textura intricata). Clamp connection abundant everywhere in the basidiocarp. Dried pileus, stipe, lamellae, basal mycelium and flesh and of the type species do not exhibit fluorescence but retain their colours under ultraviolet light (with wave-lengths $254 \mathrm{~nm}$ and $366 \mathrm{~nm}$ ), excepting the tinges of the three first-named structures which become slightly deeper. Saprophytes which decay plant litter, especially needles and leaves, sometimes herbaceous litter or woody substrates.

Clavicybe avellaneialba (Murrill) Harmaja, n. comb.

Basionym: Clitocybe avellaneialba Murrill, Mycologia 5: 207. 1913. - Material from the U.S.A. studied (Harmaja 1969).

Clavicybe clavipes (Pers. : Fr.) Harmaja, n. comb.

Basionym: Agaricus clavipes Pers., Syn. meth. fung.: 353.1801: Fr., Syst. mycol. 1: 86. 1821.Clitocybe clavipes (Pers. : Fr.) P.Kumm., Führ. Pilzk.: 124. 1871. - Omphalia clavipes (Pers. : Fr.) Quél., Enchir. fung. 20.1886.

Clavicybe squamulosoides (P.D.Orton) Harmaja, n. comb.

Basionym: Clitocybe squamulosoides P.D.Orton, Trans. Brit. Mycol. Soc. 43: 187. 1960. - Isotype examined (Harmaja 1970): U.K., England, Surrey, Witley Common, 13.XII.1956 P.D. Orton (H).

\section{Discussion}

Macroscopically, the species of this new genus are very similar to the larger non-hygrophanous species of Clitocybe (sensu Harmaja 1976). As mentioned above, Clavicybe differs from Clitocybe in two fundamental points: (i) the spore wall is rough when observed with the electron microscope (at least in the type species) vs. smooth and (ii) the hyphae of the gill trama are interwoven vs. running in parallel-subparallel direction as in Clitocybe. Also Bigelow (1982) describes the gill trama of $C$. clavipes as interwoven, likewise that of $C$. avellaneialba (as does Smith 1949). Moreover, there are two differences in the hygrophanity of the fruit body as described in the introductory section above. These unusual properties of hygrophany are apparently related to each other and they may ultimately result from some anatomical peculiarity of the whole fruit body. The interwoven gill trama may also be involved.

The direction in which the hyphae are running in the trama of the lamellae is diagnostic in the Agaricales, especially at the generic level, e.g. characterizing the genus Camarophyllus (Fr.) P.Kumm. (Singer 1986).

Of the three species included in Clavicybe, $C$. clavipes is distributed over a wide area in the northern hemisphere, $C$. avellaneialba is restricted to western North America, and the poorly known $C$. squamulosoides has been found in temperate western Europe. In addition, a fungus which is sometimes called as "the pale-brown form of Clitocybe clavipes" occurs in the temperate deciduous woods of Central Europe. A good coloured photograph of the last-named fungus was published by Phillips (1981, p. 48, as Clitocybe clavipes). This taxon may be a fourth species of Clavicybe, or it falls within the variability of $C$. squamulosoides. Also the typical dark grey-brown $C$. clavipes decays, besides needles, leaf litter, often leaves of Betula; I myself have found it in the leaves of the beech $(\mathrm{Fa}$ gus sylvatica) near Femsjö, Sweden. 


\section{A key to the species of Clavicybe}

1 Spores ca. $6-9 \times 3.5-5.3 \mu \mathrm{m}$, variable in shape; on litter of needles or leaves 2

1' Spores ca. 8-10 $\times 4.0-5.5 \mu \mathrm{m}$, broadly fusiform; mostly on much decayed woody substrates (western North America) C. avellaneialba

2 Cap and stipe dark in colour, grey-brown or sepia brown; stipe distinctly clavate; in litter of needles or leaves; widely distributed C. clavipes 2' Cap and stipe pale brown or avellaneous; stipe hardly enlarged downwards; mostly in leaf litter; temperate woods of western Europe C. squamulosoides

\section{CYSTODERMELLA}

Fayod (1889) included partly unrelated species in his new genus Cystoderma Fayod (see Smith \& Singer 1945). Heinemann \& Thoen (1973) delimit the genus in a most appropriate way, and their delimitation is essentially the current one. An universal veil possessing a thick outer layer of spherocysts is the conspicuous main diagnostic character of the genus. However, since the 1930's it has been known that the species of the genus can be assorted to two groups: those with amyloid spores and those with an inamyloid spore wall. The lectotype of the genus is $C$. amianthinum (Scop.) Konrad \& Maubl. with amyloid spores (selected by Smith \& Singer 1945). Generally, the genus has been divided into two sections: sect. Cystoderma and sect. Granulosa (Fr.) Locq. (type C. granulosum (Batsch : Fr.) Kühner) (see e.g. Singer 1986).

For decades, I have personally been interested in Cystoderma and made research on the genus. Now I have (i) evaluated the taxonomic weight of the spore difference within Cystoderma mentioned above, (ii) considered some previously unused, less exact differences or tendencies present in the genus (see Table 1), (iii) applied the results of a recent contribution on the nuclear DNA content of some species (Saar \& Kullman 2000) as well as (iv) taken into consideration the results of the phylogenetic analysis of Moncalvo \& al. (2002). My judgement, based on the above, is that Cystoderma, as currently understood (Heinemann \& Thoen 1973, Singer 1986), has to be split into two genera: Cystoder$m a$ s. str. will comprise species that possess amyloid spores while a new genus has to be established for species with inamyloid spores. Cysto- dermella Harmaja (type C. granulosum) is described below for the latter species group.

\section{Cystodermella Harmaja, n. gen.}

Agaricus subg. Lepiota [sect.?] Granulosi Fr., Hymenomyc. eur.: 35. 1874. - Lepiota [sect.?] Granulosae (Fr.) Quél., Enchir. fung.: 7. 1886. Cystoderma sect. Granulosa (Fr.) Locq., Bull. Soc. Linn. Lyon 14: 88. 1945. - Cystoderma subg. Granulosa (Fr.) Wasser, Fl. grib. Ukrainy: 209. 1980. - Type: Agaricus granulosus Batsch: Fr.

Cystoderma sect. Cinnabarina Heinem. \& Thoen, Bull. Soc. Mycol. France 89: 23. 1973. Type: Agaricus cinnabarinus Alb. \& Schwein. : Fr.

Agaricalium generis Cystodermatis proxima. Ab eo inter alia differt tunica sporarum totaliter inamyloidea. - Typus: Cystodermella granulosa (Batsch : Fr.) Harmaja (Agaricus granulosus Batsch : Fr.).

Agaricales; habitus of basidiocarp as in Cystoderma. Universal veil present. Pileus convex or plane; surface finely to coarsely granulose. Stipe covered with veil remnants except at apex; ring mostly lacking, sometimes present. Lamellae narrowly to broadly adnate. Flesh of stipe and pileus of continuous elasticity. Conidia (arthrospores) absent from context of pileus. Odour indistinct. Taste mild. Spores white in deposit, binucleate (Saar \& Kullman 2000: three species examined, the type included), ellipsoid; wall without germpore, smooth, inamyloid, cyanophilic (at least in type species: Singer 1972). Cystidia of lamellae mostly absent; when present they are 'harpoon- 
like' due to encrusted crystals. Cortex of pileus and stipe (apex excluded) formed by dry velar layer essentially composed of sphaerocysts. Hymenophoral trama of more or less parallel hyphae. Clamp connections present in hyphae of fruit body. Dried pileus, stipe, lamellae, flesh and basal mycelium of the type species do not exhibit fluorescence but retain their colours under ultra- violet light (with wave-lengths $254 \mathrm{~nm}$ and 366 $\mathrm{nm}$; no difference to $C$. amianthinum; these are apparently the first observations on the responses of Cystoderma s. lato fruitbodies to ultraviolet light). Saprophytes of non-ligneous, rarely ligneous, plant litter; sometimes among mosses at the same time but probably not truly muscicolous.

\section{Comparison of the genera Cystoderma and Cystodermella}

Table 1. A comparison of Cystoderma Fayod and Cystodermella Harmaja. The exact differences are given in bold. See the text immediately below for details and references.

\begin{tabular}{|c|c|c|}
\hline & Cystoderma & Cystodermella \\
\hline Spore wall in Melzer's & amyloid & inamyloid \\
\hline 'Harpoon' cystidia & absent & present in some species \\
\hline $\begin{array}{l}\text { Arthrospores in fruit body and/or } \\
\text { mycelium culture }\end{array}$ & Present in some species (e.g. type) & unknown \\
\hline Liability to Squamanita & type species susceptible & resistant \\
\hline Bryophily & often strong & often not apparent \\
\hline $\begin{array}{l}\text { Ploidy level } \\
\text { (both type species studied) }\end{array}$ & $2 \times$ & $3 x$ or $6 x$ \\
\hline Phylogeny & $\begin{array}{l}\text { type species clusters near } \\
\text { Floccularia Pouz. }\end{array}$ & $\begin{array}{l}\text { type species clusters } \\
\text { near Ripartitella Sing. }\end{array}$ \\
\hline
\end{tabular}

The spore wall of C. superbum Huijsman is commonly reported to be amyloid in a small area only, above the hilar appendix (e.g. Heinemann \& Thoen 1973). However, according to the observations of Pegler \& Young (1971) the spore wall is weakly amyloid throughout, but the area mentioned (the plage) is strongly amyloid.

Kühner (1969) reported the occurrence of conidia (arthrospores) in the flesh of the fruit body and/or in the mycelium culture of some Cystoderma taxa with amyloid spores. Heinemann \& Thoen (1973) and Harmaja (1979) likewise noted the presence of the arthrospores in the basidiocarps of some amyloid-spored species, including the type.

Saar \& Kullman (2000) analyzed the nuclear DNA content (genome size, ploidy level, $C$ value) of six species of current Cystoderma from the spore nuclei. They found that all three species with amyloid spores (C. carcharias (Pers.) Konrad \& Maubl., C. jasonis (Cooke \& Massee) Harmaja and C. amianthinum, the type of the genus) were on $2 \times$ ploidy level while the nuclei of three other species, belonging to the group with in- amyloid spores, contained higher amounts of DNA: $C$. adnatifolium (Peck) Harmaja and $C$. granulosum were on $3 \times$ level and $C$. cinnabarinum (Alb. \& Schw. : Fr) Konrad \& Maubl. (as $C$. terreii (Berk. \& Broome) Harmaja) was on $6 \times$ level.

The species of Squamanita Imbach (Agaricales) parasitize other agarics. They develop chimeric basidiocarps which are mixtures of the structures and tissues of the fruit bodies of the host and the parasite (Harmaja 1988, Redhead \& al. 1995). Observations on these chimera fruitbodies and the agaric species growing in their immediate neighbourhood suggest that always when a Cystoderma s. lato is contaminated with Squamanita, it is C. amianthinum (Smith \& Singer 1948, Watling 1974, Reid 1983, Harmaja 1988, Lange \& Læssøe 1989, Stridvall \& Stridvall 1994, Redhead \& al. 1995) or C. carcharias (Eriksen 1997).

In the woods or on rock outcrops, species of Cystoderma s. str., in particular, very often grow in a moss carpet with their basal mycelium tightly attached to living mosses. My field experience 
even suggests that two species, at least (C. lilacipes Harmaja and C. saarenoksae Harmaja) are obligately associated with species of Polytrichum s. str. (Harmaja 1979a, 1985).

In the comprehensive phylogenetic work of Moncalvo \& al. (2002) Cystoderma amianthinum and $C$. chocoanum Franco-Molano (likewise with amyloid spores) clustered with $\mathrm{Floccu}$ laria albolanaripes (G.F.Atk.) Redhead (with amyloid spores) while C. granulosum clustered in another clade with Ripartitella brasiliensis (Speg.) Singer (with inamyloid spores and often harpoon cystidia).

\section{Discussion}

The presence of a partial veil in Cystodermella remains to be ascertained. In $C$. adnatifolia, in particular, a whorl of white hyphae remains at the 'ring zone' of the stipe. It is unclear whether this tissue represents a separate partial veil or is formed from the inner layer of the universal veil.

Besides Cystoderma s. str., also Ripartitella Singer is closely related to Cystodermella. $R i$ partitella differs from Cystodermella: (i) a perfect universal veil is lacking, (ii) the cortical layers of the pileus and stipe are composed of elongated cells instead of sphaerocysts, and (iii) the spores are verruculose (Singer 1986).

The placement of current Cystoderma within the Agaricales is somewhat problematic: it has been included in the families Agaricaceae, Lepiotaceae and Tricholomataceae (e.g., Heinemann \& Thoen 1973, Kühner 1980, Singer 1986, Harmaja 1979a). Pegler \& Young $(1969,1971)$ published two interesting observations: in $C$. amianthinum the structure of hilar appendix of the spore is of the nodulose type, and the spore wall appeared thin and got easily collapsed under vacuum when carbon replicas were produced. As they pointed out, both these characters of $C$. amianthinum show affinities to the fungi of Tricholomataceae with their hyaline thin-walled spores rather than to Agaricaceae/Lepiotaceae. Unfortunately they did not examine the spore ultrastructure of $C$. granulosum or any other species with inamyloid spores. In the phylogenetic study of Moncalvo \& al. (2002) the proper placements of the type species of Cystoderma and Cystodermella among the euagarics remained unresolved.

For additional information of Cystodermella: see the descriptions of the section Granulosa in
Smith \& Singer (1945), Heinemann \& Thoen (1973; some species are treated in sect. Cinnabarina Heinem. \& Thoen) and Singer (1986).

At least 12 species of Cystodermella are well defined, the area of the genus extending from the tropical to the arctic zone. Cystoderma s. str. comprises roughly 17 species at present; the distribution of the genus is subcosmopolitan and extends from the arctic through the tropics to subantarctic regions. In both genera, north temperate and boreal zones with a not too continental climate display the greatest diversity known at present; my observations suggest that several undescribed species exist. For treatments of world species, consult Smith \& Singer (1945), Heinemann \& Thoen (1973) and Singer (1986).

Those species are transferred to the genus Cystodermella which are familiar to me or which appear distinct enough and well described in the literature.

\section{New combinations in Cystodermella}

Cystodermella adnatifolia (Peck) Harmaja, n. comb.

Basionym: Lepiota adnatifolia Peck, Bull. New York State Mus. Nat. Hist. 54: 947. 1902. - Armillaria adnatifolia (Peck) Kauffman, Pap. Michigan Acad. Sci. 2: 60. 1923. - Cystoderma granulosum var. adnatifolium (Peck) A.H.Sm. \& Singer, Pap. Michigan Acad. Sci. 30: 90. 1945. - Cystoderma adnatifolium (Peck) Harmaja, Karstenia 14: 122. 1974.

Cystodermella ambrosii (Bres.) Harmaja, n. comb.

Basionym: Armillaria ambrosii Bres., Fungi Tridentini 1: 27. 1881. - Cystoderma ambrosii (Bres.) Singer, Ann. Mycol. 41: 170. 1943.

Cystodermella cinnabarina (Alb. \& Schwein. : Fr.) Harmaja, n. comb.

Basionym: Agaricus A. [unranked Lepiotae] granulosus var. ee cinnabarinus Alb. \& Schwein., Consp. Fung. Lusat.: 147. 1805. - Agaricus cinnabarinus (Alb. \& Schwein. : Fr.) Fr., Syst. mycol. 3: Index: 12. 1832. - Lepiota cinnabarina (Alb. \& Schwein. : Fr.) P.Karst., Bidrag Kännedom Finlands Natur Folk 32 (Ryssl. Hattsvamp. 1]: 14. 1979. - Armillaria cinnabarina (Alb. \& Schwein. : Fr.) Kauffman, Pap. Michigan Acad. 
Sci. 2: 60. 1923. - Cystoderma cinnabarinum (Alb. \& Schwein. : Fr.) Konrad \& Maubl., Icon. sel. fung. 3(3): pl. 238. 1927.

Agaricus terryi ('Terreii') Berk. \& Broome, Ann. Mag. Nat. Hist. 4(6): 462. 1870. - Cystoderma terryi (Berk. \& Broome) Harmaja, Karstenia 18:30. 1978.

Bon (1999) correctly points out that, in the index of Systema mycologicum, published at the end of its third part, Fries used and even sanctioned the epithet cinnabarinus at the specific level, so that epithet shall be used for the present species rather than terryi as I earlier (Harmaja 1979a) suggested.

Cystodermella contusifolia (Pegler) Harmaja, n. comb.

Basionym: Cystoderma contusifolium Pegler, Kew Bull., Addit. Ser. 9: 410. 1983.

Cystodermella cristallifera (Thoen) Harmaja, n. comb.

Basionym: Cystoderma cristalliferum Thoen, Bull. Jard. Bot. Belg. 39: 185. 1969.

Cystodermella elegans (Beeli) Harmaja, n. comb.

Basionym: Armillaria elegans Beeli, Bull. Soc. Roy. Bot. Belgique 59: 111. 1927. - Cystoderma elegans (Beeli) Thoen, Bull. Jard. Bot. Belg. 39: 188. 1969.

Cystodermella granulosa (Batsch : Fr.) Harmaja, n. comb.

Basionym: Agaricus granulosus Batsch, Elench. fung. 1: 170. 1783: Fr., Syst. mycol. 1: 24. 1821.Lepiota granulosa (Batsch : Fr.) Gray, Nat. arrang. Brit. pl. 1: 602. 1821. - Mastocephalus granulosus (Batsch : Fr.) Kuntze, Rev. gen. pl. 2: 860. 1891. - Armillaria granulosa (Batsch : Fr.) Kauffman, Pap. Michigan Acad. Sci. 2: 60. 1923. [non Armillaria granulosa Vel., Opera Bot. Čech.
4 [Nov. mycol. noviss.]: 57. 1947; = ?] - Cystoderma granulosum (Batsch : Fr.) Kühner, Botaniste 17: 125. 1926.

Cystodermella japonica (Thoen \& Hongo) Harmaja, n. comb.

Basionym: Cystoderma japonicum Thoen \& Hongo, Trans. Mycol. Soc. Japan 26: 23. 1985.

Cystodermella luteohemisphaerica (Dennis) Harmaja, n. comb.

Basionym: Cystoderma luteohemisphaericum Dennis, Kew Bull. 15: 109. 1961.

Cystodermella myriadocystis (Heinem. \& Thoen.) Harmaja, n. comb.

Basionym: Cystoderma myriadocystis Heinem. \& Thoen, Bull. Soc. Mycol. France 89: 14. 1973.

Cystodermella sipariana (Dennis) Harmaja, n. comb.

Basionym: Lepiota sipariana Dennis, Kew Bull. 7: 488. 1953. - Cystoderma siparianum (Dennis) Thoen, Bull. Jard. Bot. Belg. 39: 190. 1969. - Ripartitella sipariana (Dennis) Dennis, Kew Bull., Addit. Ser. 3: 58. 1970.

C. subpurpurea (A.H.Sm. \& Singer) Harmaja, n. comb.

Basionym: Cystoderma subpurpureum A.H.Sm. \& Singer, Mycologia 40: 457. 1948.

Acknowledgements: The Lammi Biological Station of the University of Helsinki has provided me excellent research facilities during many years. Thanks are due to the curators of those herbaria which have lent material for my studies during years. Professor Teuvo Ahti made useful improvements to the manuscript. Mr. Heino Vänskä, Lic. Phil., kindly checked the Latin of the generic descriptions. 


\section{References}

Astapenko, V.V. \& Kutafyeva, N.P. 1990: Dopolnenie k flore makromitsetov srednego Priangar'a. - Novosti Sist. Nizsh. Rast. 27: 48-52.

Bigelow, H.E. 1981: Spore ornamentation in the Tricholomataceae 1. - Mycologia 73: 128-140.

Bigelow, H.E. 1982: North American species of Clitocybe. Part 1. - Beih. Nova Hedwigia 72: 1-280.

Bon, M. 1999: Novitates: Tricholomatales (Marasmiaceae, Lyophyllaceae et Dermolomataceae). Doc. Mycol. 29(115): 33-34.

Bresadola, J. 1927: Iconographia mycologica. Vol. 1. Pls. 1-50. Mediolani.

Bresinsky, A. \& Besl, H. 1985: Giftpilze. - 295 pp. Wissenschaftliche Verlagsgesellschaft $\mathrm{mbH}$, Stuttgart.

Cifuentes, J., Pérez-Ramírez, L. \& Villegas, M. 1989: Descripción de macromicetos poco estudiados en México III. - Rev. Mexic. Micol. 5: 101-115.

Cochran, K.W. \& Cochran, M.W. 1978: Clitocybe clavipes: Antabuse-like reaction to alcohol. - Mycologia 70: 1124-1126.

Eriksen, A. 1997: Andet danske fund av gulstokket knolfod (Squamanita paradoxa). - Svampe 35: 55.

Fayod, V. 1889: Prodrome d'une histoire naturelle des Agaricinées. - Ann. Sci. Nat., Bot., sér. 7,9: 181-411.

Gorbunova, A.I. 2001: Novye svedeniya o mikobiote Respubliki Altay. - Novosti Sist. Nizsh. Rast. 35: 5770.

Harmaja, H. 1969: The genus Clitocybe (Agaricales) in Fennoscandia. - Karstenia 10: 5-168.

Harmaja, H. 1970: Type studies on Agaricales described as Clitocybe and Omphalina. - Karstenia 11: 35-40.

Harmaja, H. 1974a: A revision of the generic limit between Clitocybe and Lepista. - Karstenia 14: 82-92.

Harmaja, H. 1974b: Singerella n. gen., a separate genus for Clitocybe hydrogramma. - Karstenia 14: 113115.

Harmaja, H. 1976: A further revision of the generic limit between Lepista and Clitocybe. - Karstenia 15: 13-15.

Harmaja, H. 1979a: Studies in the genus Cystoderma. Karstenia 19: 25-29.

Harmaja, H. 1979b: Type studies in Clitocybe 4. Karstenia 19: 50-51.

Harmaja, H. 1985: Studies on white-spored agarics. Karstenia 25: 41-46.

Harmaja, H. 1988: Studies on the agaric genera Singerocybe n. gen. and Squamanita. - Karstenia 27: 71-75.

Heinemann, P. \& Thoen, D. 1973: Observations sur le genre Cystoderma. - Bull. Soc. Mycol. France 89: 534.

Karsten, P.A. 1883: Icones selectae Hymenomycetum Fenniae nondum delineatorum. 1. - 15 pp. + Pls. 110. Helsingforsiae.

Knudsen, H. 1980: A revision of Lepiota sect. Echinatae and Amyloideae (Agaricaceae) in Europe. - Bot. Tidsskr. 75: 121-155.

Kotiranta, H., Uotila, P., Sulkava, S. \& Peltonen, S.-L. (eds.) 1998: Red Data Book of East Fennoscandia. 351 pp. Ministry of the Environment, Finnish Environment Institute \& Botanical Museum, Finnish Museum of Natural History, Helsinki.
Kühner, R. 1945: Le problème de la filiation des Agaricales à la lumière de nouvelles observations d'ordre cytologique sur les Agaricales leucosporées. - Bull. Soc. Mycol. Linn. Lyon 14: 160-169.

Kühner, R. 1969: Cystoderma amianthinum (Scop. ex Fr.) Fayod, var. longisporum (Kühner) Smith et Singer et var. sublongisporum Singer. - Bull. Soc. Linn. Lyon 38: $178-188$.

Kühner, R. 1980: Les grandes lignes de la classification des Agaricales, Pluteales, Tricholomatales (suite). Bull. Soc. Linn. Lyon 49: 297-344.

Kutafyeva, N.P. 1989: K flore gribov-makromitsetov Srednego Priangar'a. 4. - Novosti Sist. Nizsh. Rast. 26: 65-67.

Lange, C. \& Læssøe, T. 1989: Gulstokket Knoldfod (Squamanita paradoxa) - et sjældent og mærkeligt fund. - Svampe 19: 35-36.

Lapitskaya, L.S. 1993: K flore gribov-makromitsetov srednego Yeniseya. 2. - Novosti Sist. Nizsh. Rast. 29: $45-48$.

Miller, O.K. Jr., Volk, T.J. \& Bessette, A.E. 1996: A new genus, Leucopholiota, in the Tricholomataceae (Agaricales) to accommodate an unusual taxon. Mycologia 88: 137-139.

Moncalvo, J.-M., Vilgalys, R., Redhead, S.A., Johnson, J.E., James, T.Y., Aime, M.C., Hofstetter, V., Verduin, S.J.W., Larsson, E., Baroni, T.J., Thorn, R.G., Jacobsson, S., Clémençon, H. \& Miller, O.K. Jr. 2002: One hundred and seventeen clades of euagarics. - Mol. Phyl. Evol. 23: 357-400.

Moser, M. 1979: Über einige neue or seltene AgaricalesArten aus dem Pieniny und aus Biesczciade, Polen. Beih. Sydowia 8: 268-275.

Nezdojminogo, E.L. 1982: K flore agarikovykh gribov severnoy chasti Krasnoyarskogo kraya. 2. - Novosti Sist. Nizsh. Rast. 19: 73-77.

Peck, C.H. 1873: Report of the Botanist. - Rep. State Bot. New York State Mus. 25: 57-123 + Pls. 1-2.

Pegler, D.N. \& Young, T.W.K. 1969: Ultrastructure of basidiospores in Agaricales in relation to taxonomy and spore discharge. - Trans. Brit. Mycol. Soc. 52: 491-496 + Pls. 36-37.

Pegler, D.N. \& Young, T.W.K. 1971: Basidiospore morphology in the Agaricales. - Beih. Nova Hedwigia 35: $1-210$ + Pls. 1-53.

Petrov, A.N. 1986: K flore agarikovykh gribov yugozapadnogo poberezh'a ozera Baykal. 2. - Novosti Sist. Nizsh. Rast. 23: 152-158.

Phillips, R. 1981: Mushrooms and other fungi of Great Britain and Europe. - 288 pp. Pan Books Ltd, London.

Rassi, P., Alanen, A., Kanerva, T. \& Mannerkoski, I. (toim.) 2001: Suomen lajien uhanalaisuus 2000 (English summary: The 2000 Red List of Finnish species). - 432 pp. Ympäristöministeriö \& Suomen ympäristökeskus, Helsinki.

Redhead, S.A., Ammirati, J.F., Walker, G.R., Norvell, L.L. \& Puccio, M.B. 1995: Squamanita contortipes, the Rosetta Stone of a mycoparasitic agaric genus. Canad. J. Bot. 72: 1812-1824. 
Reid, D.A. 1983: A second British collection of Squamanita paradoxa. - Bull. Brit. Mycol. Soc. 17: 111113.

Romagnesi, H. 1989: Quelques synonymies méconnues. - Bull. Soc. Mycol. France: 105: 253-257.

Saar, I. \& Kullman, B. 2000: Nuclear DNA content and spore dimension in some species of the genus Cystoderma. - Folia Cryptog. Estonica 36: 87-94.

Singer, R. 1943: Das System der Agaricales. 3. - Ann. Mycol. 41: 1-189.

Singer, R. 1972: Cyanophilous spore walls in the Agaricales and agaricoid Basidiomycetes. - Mycologia 64: 822-829.

Singer, R. 1986: The Agaricales in modern taxonomy. Ed. 4. -981 pp. + Pls. 1-88. Koeltz Scientific Books, Königstein.
Smith, A.H. 1949: Mushrooms in their natural habitats. 1. Text. -626 pp. Sawyer's Inc., Portland.

Smith, A.H. \& Singer, R. 1945: A monograph on the genus Cystoderma. - Pap. Michigan Acad. Sci. 30: $71-124+$ Pls. I-V.

Smith, A.H. \& Singer, R. 1948: Notes on the genus Cystoderma. - Mycologia 40: 454-460.

Stridvall, L. \& Stridvall, A. 1994: Släktet Squamanita Imbach i Sverige. - Jordstjärnan 15: 24-37.

Vasil'eva, L.N. 1973: Agarikovye shlyapochnye griby (por. Agaricales) Primorskogo kraya. - 331 pp. + pls. I-II. Nauka, Leningrad.

Watling, R. 1974: Notes on some British agarics: 4. Notes Roy. Bot. Gard. Edinburgh 33: 325-331. 